\title{
Modul pembelajaran problem-based learning berbasis lahan basah untuk mempersiapkan calon pendidik berwawasan lingkungan lahan basah
}

\author{
Rilia Iriani *, Anna Herlina, Yudha Irhasyuarna, Rahmat Eko Sanjaya \\ Program Studi Pendidikan Kimia, Fakultas Keguruan dan Ilmu Pendidikan, \\ Universitas Lambung Mangkurat. \\ Jalan Brigjend. H. Hasan Basri Kayu Tangi, Banjarmasin 70123, Indonesia. \\ *Coressponding Author. E-mail: rilia_kimia@ulm.ac.id \\ Received: 28 january 2019; Revised: 11 February 2019; Accepted: 21 February 2019
}

\begin{abstract}
Abstrak
Menghasilkan pendidik dan tenaga kependidikan berwawasan lingkungan lahan basah merupakan visi dari Fakultas Keguruan dan Ilmu Pendidikan Universitas Lambung Mangkurat, Banjarmasin. Mewujudkan visi tersebut, pembelajaran yang dilakukan mengacu pada pembangunan pemahaman mahasiswa terhadap lingkungan lahan basah. Kimia Lingkungan merupakan mata kuliah yang bersentuhan langsung dengan lingkungan lahan basah. Sehingga diperlukan pengembangan modul pembelajaran Kimia Lingkungan yang berdasarkan lingkungan lahan basah. Modul dikembangkan menggunakan desain penelitian R \& D dengan model pengembangan 4-D. Subjek penelitian adalah mahasiswa pada mata kuliah Kimia Lingkungan Lahan Basah. Data yang dihasilkan berupa data validitas, keterbacaan, dan efektivitas modul serta respon siswa. Kelayakan modul pembelajaran PBL berbasis lingkungan lahan basah berada pada kategori "baik" dengan skor rata-rata 3,25. Uji keterbacaan perorangan dan kelompok kecil memiliki skor rata-rata masing-masing 3,0 dan berada pada kategori "baik". Efektivitas modul terlihat dari hasil belajar mahasiswa pada uji perorangan dan uji kelompok kecil dengan nilai masing-masing 93,8 dengan $\mathrm{N}$-gain 0,9 dan 92,6 dengan $\mathrm{N}$ gain 0,9. Mahasiswa memberikan respon "baik" dengan persentase 78,33\% untuk respon perorangan dan 71,67\% untuk uji kelompok kecil. Hasil ini menunjukkan bahwa modul pembelajaran problem-based learning (PBL) berbasis lingkungan lahan basah dinyatakan layak dan efektif untuk digunakan dalam pembelajaran Kimia Lingkungan Lahan Basah.
\end{abstract}

Kata Kunci: modul, problem-based learning, lingkungan lahan basah, model pengembangan 4D

\section{Problem-based learning module based on wetland to prepare teachers candidate with wetland environmental insight}

\begin{abstract}
Graduating teachers and educational staff with wetland environmental insight is the vision of Faculty of Teacher Training and Education Universitas Lambung Mangkurat, Banjarmasin. Realizing this vision, the learning carried out refers to building students' understanding of the wetland environment. Environmental Chemistry is a course that directly contacts with the wetland environment. Therefore, it is necessary to develop a module on Environmental Chemistry based on wetland environments. The module was developed using $R \& D$ research design with 4-D development model. The research subjects were students in Environmental Chemistry course. The data generated in the form of validity, readability and effectiveness of a module. The validity of the problem-based learning module based on wetland is in "good" category with average score 3,25. Individual and small group readability tests have an average score, respectively 3.0 and in "good" category. The effectiveness of the module can be seen from student learning achievement in individual and small group tests, respectively 93,8 with $\mathrm{N}$-gain 0,9 and 92,6 with $\mathrm{N}$-gain 0,9. The students give a "good" response with 78,33\% for individual and 71,67\% for small group responses. This results show that problem-based learning (PBL) module based on wetland environment is declared valid and effective to use in Environmental Chemistry learning.
\end{abstract}

Keywords: module, problem-based learning, wetland environmental insight, $4 \mathrm{D}$ development model

How to Cite: Iriani, R., Herlina, A., Irhasyuarna, Y., \& Sanjaya, R. E. (2019). Modul pembelajaran problem-based learning berbasis lahan basah untuk mempersiapkan calon pendidik berwawasan lingkungan lahan basah. Jurnal Inovasi Pendidikan IPA, 5(1), 54-68. doi:https://doi.org/10.21831/jipi.v5i1.23337

d.

https://doi.org/10.21831/jipi.v5i1.23337 


\section{PENDAHULUAN}

Fakultas Keguruan dan Ilmu Pendidikan (FKIP) Universitas Lambung Mangkurat (ULM) memiliki visi untuk menjadi penyelenggara dan penghasil tenaga pendidik dan tenaga kependidikan yang berkarakter, unggul dan berdaya saing pada lingkungan lahan basah. Lingkungan lahan basah merupakan penciri Universitas Lambung Mangkurat dibandingkan dengan universitas lain di Indonesia. Segala kegiatan dan proses pengembangan pembelajaran berorientasi pada wawasan lingkungan lahan basah. Wawasan lingkungan lahan basah merupakan sebuah pemahaman untuk memberdayakan lingkungan atau kawasan yang sebagian atau seluruhnya kadang-kadang tergenangi oleh lapisan air dangkal. Lahan basah adalah wilayah payau, rawa, gambut, atau perairan, baik alami maupun buatan, permanen atau temporer (sementara), dengan air yang mengalir atau diam, tawar, payau, atau asin, termasuk pula wilayah dengan air laut yang kedalamannya di saat pasang rendah (surut) tidak melebihi 6 meter (Konvensi Ramsar) (Soendjoto, 2016).

Lahan basah memiliki banyak keuntungan dan manfaat bagi masyarakat sekitar. Pengetahuan terhadap lahan basah menjadi hal penting dalam pengembangan kawasan. Masyarakat yang berada di kawasan lahan basah menginginkan adanya pemahaman tentang lahan basah, baik dalam pendidikan formal dan nonformal (Ibrahim, Aminudin, Young, \& Yahya, 2012). Secara garis besar, manfaat lahan basah dapat berupa habitat ekosistem tertentu, kontrol kualitas air, penampung air dan pencegahan terhadap banjir, serta pemanfaatan untuk bernilai ekonomis (Cocozza \& Palner, 2009; Pedersen, Weisner, \& Johansson, 2019; Soendjoto, 2016). Keanekaragaman hayati yang terdapat dalam lahan basah merupakan kekayaan biodiversitas di lingkungan lahan basah. Pengetahuan tentang keanekaragaman hayati dan perlindungan kawasan lahan basah patut ditanamkan sejak dini demi menumbuhkan kecintaan dan pelestarian lingkungan lahan basah (Ibrahim et al., 2012).

Letak geografis FKIP ULM berada di Kota Banjarmasin, Kalimantan Selatan yang memiliki kawasan berupa lahan basah. Kondisi geografis seperti ini menjadikan FKIP ULM untuk memanfaatkan potensi kawasan lahan basah sebagai sumber dan kajian pembelajaran. Pembelajaran rumpun sains yang meliputi Kimia, Fisika dan Biologi, dapat memanfaatkan kawasan lahan basah sebagai sumber belajar. Biologi dapat memelajari dan memanfaatkan keanekaragaman hayati di lingkungan lahan basah. Kimia juga dapat mengeksprolarasi berbagai potensi kimiawi di lingkungan lahan basah. Salah satu bagian cabang ilmu Kimia yang dapat bersentuhan langsung dengan lingkungan lahan basah adalah Kimia Lingkungan. Pembelajaran yang berbasis pada potensi lokal dapat menjadi kekuatan dan peluang yang harus dioptimalkan oleh FKIP ULM untuk dapat menjadi institusi yang unggul dan kompetitif.

Kimia Lingkungan Lahan Basah merupakan mata kuliah penciri di Program Studi Pendidikan Kimia untuk mengakomodasi potensi lingkungan lahan basah di Kalimantan Selatan. Kimia Lingkungan Lahan Basah merupakan mata kuliah yang mengacu pada KKNI dan pembahasan yang menekankan kepada aspek kimia lingkungan di kawasan lahan basah. Mata kuliah ini sebelumnya bernama Kimia Lingkungan dan termasuk dalam Mata Kuliah Bidang Keahlian (MKBK) yang bertujuan untuk membekali mahasiswa tentang lingkungan ditinjau dari aspek kimia, seperti yang tercantum pada Keputusan Rektor Universitas Lambung Mangkurat No. 745/UN8/KR/2017 tentang Kurikulum Program Studi Pendidikan Kimia FKIP ULM. Salah satu materi kuliah dalam Kimia Lingkungan adalah Pencemaran Air. Materi kuliah ini berisikan bentuk permasalahan, penyebab, penanggulangan dan polutan kimiawi yang terdapat di perairan. Oleh karena materi kuliah Kimia Lingkungan Lahan Basah mengacu pada lahan basah, maka pembahasan tentang pencemaran air pun mengacu pada pencemaran air di kawasan lahan basah.

Mata kuliah Kimia Lingkungan Lahan Basah memiliki kekhasan tersendiri dibandingkan dengan mata kuliah kimia lingkungan yang diajarkan pada Peguruan Tinggi lainnya. Mata kuliah ini mengajarkan mahasiswa untuk mengkaji lingkungan berdasarkan potensi lokal yang dimiliki, yaitu lingkungan lahan basah. Pembelajaran pada mata kuliah ini berorientasi pada daerah atau kawasan lingkungan lahan basah. Sehingga bahan ajar yang digunakan pun harus memenuhi unsur-unsur kimia lingkungan pada kawasan lahan basah.

Materi pada mata kuliah Kimia Lingkungan yang disajikan dalam buku-buku acuan perkuliahan merupakan konsep umum dari Kimia Lingkungan. Penambahan potensi lokal berupa lingkungan lahan basah dalam materi Kimia Lingkungan, diperlukan bahan acuan baru berupa pembahasan Kimia Lingkungan yang mengacu 
Jurnal Inovasi Pendidikan IPA, 5 (1), 2019 - 56

Rilia Iriani, Anna Herlina, Yudha Irhasyuarna, Rahmat Eko Sanjaya

pada lahan basah. Bahan acuan atau bahan perkuliahan tersebut dapat berupa modul pembelajaran yang memuat topik bahasan tertentu dari materi Kimia Lingkungan. Modul pembelajaran dibuat untuk dapat mengakomodasi potensi lokal yang dapat dikaji dan menjadi permasalahan otentik sebagai kajian ilmiah dalam perkuliahan. Oleh karena itu, diperlukan modul pembelajaran Kimia Lingkungan yang berorientasi pada lingkungan lahan basah untuk dapat dikembangkan sehingga menjadi acuan dalam perkuliahan Kimia Lingkungan Lahan Basah.

Modul merupakan suatu cara pengorganisasian materi pelajaran yang memperhatikan fungsi pendidikan. Strategi pengorganisasian materi pembelajaran mengandung sequencing atau pengurutan materi yang mengacu pada pembuatan urutan penyajian materi pembelajaran, dan synthesizing atau sintesis materi yang mengacu pada upaya untuk menunjukkan kepada mahasiswa keterkaitan antara fakta, konsep, prosedur dan prinsip yang terkandung dalam materi pembelajaran (Parmin \& Peniati, 2012). Modul merupakan bahan ajar yang disusun secara sistematis dan menarik yang mencakup isi materi, metode, dan evaluasi yang dapat digunakan secara mandiri dan bersifat lebih objektif (Pummawan, 2007). Pembelajaran dengan menggunakan modul bertujuan agar mahasiswa mampu belajar secara mandiri, peran pengajar tidak mendominasi dan tidak otoriter dalam pembelajaran, serta dapat mengakomodasi berbagai tingkat dan kecepatan belajar siswa (Sukiminiandari, Budi, \& Supriyati, 2015). Salah satu modul yang dapat membantu siswa dalam melatih kemadirian dan berhadapan dengan masalah otentik adalah modul dengan basis pengembangan berupa masalah atau dikenal dengan modul berbasis Problem-Based Learning (PBL).

Modul berbasis Problem-Based Learning atau modul PBL merupakan modul yang dikembangkan dengan berorientasi pada masalah sebagai titik awal pembelajaran. Modul PBL menyajikan masalah otentik yang berkaitan langsung dengan kehidupan sehari-hari. Masalah yang disajikan dapat berupa kasus teoritikal maupun praktikal berbasis kerja laboratorium. Masalah yang disajikan dalam modul dapat mengembangkan kemampuan berpikir (minds on activity) karena mahasiswa mencari, mengolah dan menyimpulkan sendiri atas masalah yang dipelajari (Levin, 2001). Prinsip dasar dalam PBL adalah adanya masalah, pertanyaan, atau teka-teki yang membuat siswa ingin memecahkannya (Duch, Allen \& White, 1997). Pembelajaran dengan menggunakan PBL terbukti memberikan dampak positif dalam kemandirian, motivasi, minat dan penguatan konsep siswa dalam pembelajaran (Tosun \& Senocak, 2013; Tosun \& Taskesenligil, 2012; Etherington, 2011; de Graaff \& Kolmos, 2003). Modul yang dikembangkan dengan berbasis PBL memberikan hasil berupa peningkatan keterampilan mahasiswa (Kushartanti, 2010; Lestari, Fajaruddin, \& Sacko, 2018), literasi mahasiswa (Febriasari \& Supriatna, 2017; Febrina, Ashadi \& Masykuri, 2014), kemampuan berpikir kritis, kreatif, analitis dan sikap peduli lingkungan (Lestari \& Projosantoso, 2016; Yarid \& Ariswan, 2016; Primarinda, Prayitno \& Maridi, 2014), efektif meningkatkan aspek belajar kognitif dan afektif (Febriana, Ashadi \& Masykuri, 2014) serta kompetensi mahasiswa (Jeong, Shin, Shin, $\&$ Bae, 2017).

Hasil wawancara dengan mahasiswa Program Studi Pendidikan Kimia FKIP ULM Banjarmasin menunjukkan bahwa materi pencemaran air pada mata kuliah Kimia Lingkungan Lahan Basah hanya berdasarkan konsep umum yang tersajikan dalam buku teks. Konten materi pencemaran air yang hanya bersifat umum, kurang mengakomodasi potensi lokal dan contoh yang disajikan kurang otentik. Penyajian materi pembelajaran yang berbasis pada masalah otentik dan terjadi di lingkungan sekitar merupakan hal yang menarik untuk dieksplorasi. Pembelajaran dengan berorientasi pada masalah yang terjadi di lingkungan, khususnya lingkungan lahan basah, dapat menjadi hal yang memiliki daya tarik bagi mahasiswa untuk dipelajari. Konsep dalam pencemaran air berupa indikator pencemaran air yang meliputi DO, COD \& BOD, dapat dipelajari secara langsung di lingkungan lahan basah.

Penelitian ini bertujuan untuk mengembangkan modul perkuliahan Kimia Lingkungan berbasis PBL yang berorientasi pada lingkungan lahan basah. Melalui modul ini, mahasiswa diajak untuk mempelajari permasalahan lingkungan berupa pencemaran air yang terjadi di lingkungan lahan basah. Modul disusun sedemikian rupa sehingga dihasilkan sebuah struktur materi perkuliahan yang mengajarkan materi pencemaran air di lingkungan lahan basah. Pada modul ini mahasiswa diajak untuk membentuk pengetahuannya sendiri tentang pencemaran air dengan praktik langsung ke kawasan lahan basah di desa Tanipah, Kecamatan Aluh-Aluh, Kabupaten Banjar, Kalimantan Selatan. Kerberhasilan pengembangan modul dilihat dari tingkat kelayakan 
modul berdasarkan hasil validasi oleh pakar, kepraktiksan berupa tingkat keterbacaan dan efektivitas modul. Subjek dalam penelitian pengembangan ini adalah mahasiswa Program Studi Pendidikan Kimia FKIP ULM yang memprogram mata kuliah Kimia Lingkungan Lahan Basah semester ganjil 2017/2018.

\section{METODE}

Metode yang digunakan pada penelitian ini adalah metode R \& D (Research and Development) dengan model pengembangan 4-D menurut Thiagarajan, Semmel, dan Semmel (1974) yang memiliki 4 tahapan yaitu define (pendefinisian), design (perencanaan), develop (pengembangan), disseminate (penyebaran). Pada tahap pendefinisian, terdapat beberapa langkah yang dilakukan yaitu analisis mahasiswa, analisis konsep dan analisis tugas. Tahap perencanaan dilakukan dengan penyusunan instrumen tes, pemilihan format, dan desain awal modul. Selanjutnya, pada tahap pengembangan dilakukan modifikasi produk yang dihasilkan pada tahap perancangan, sebelum menjadi produk akhir yang siap untuk digunakan. Pada tahap ini dilakukan uji kelayakan modul yang meliputi uji validitas, uji praktikalitas modul berupa uji keterbacaan dan respon mahasiswa, serta uji efektifitas modul. Tahap penyebaran belum dilakukan dalam penelitian ini, sehingga hanya tiga dari empat tahap model pengembangan yang dilaksanakan.

Penelitian dilakukan di FKIP ULM dengan subjek penelitian adalah mahasiswa Program Studi Pendidikan Kimia yang memprogram mata kuliah Kimia Lingkungan Lahan Basah semester ganjil 2017/2018. Objek dalam penelitian ini adalah modul PBL berbasis lingkungan lahan basah yang dikembangkan. Pada tahap pengembangan, subjek penelitian selain pembelajaran di kelas, juga melakukan pembelajaran lapangan di daerah lahan basah untuk mempelajari keadaan lingkungan secara langsung berupa pencemaran yang terjadi. Pembelajaran langsung ke lapangan merupakan bagian dari pelaksanaan pembelajaran dengan modul PBL berbasis lahan basah. Pembelajaran yang dilakukan merupakan pengambilan sampel air sungai di Desa Tanipah Kec. AluhAluh Kab. Banjar, Kalimantan Selatan. Sampel yang diperoleh diuji kualitas air berdasarkan parameter kualitas air.

Pengembangan produk awal modul PBL berbasis lahan basah berisi pendahuluan, daftar isi, kata pengantar, petunjuk penggunaan modul, kompetensi dasar, peta konsep, materi pencemaran air, tugas mandiri, tugas evaluasi, dan langkah-langkah pembelajaran lapangan berupa indikator pencemaran air. Produk awal modul dilakukan uji validasi oleh pakar. Validasi modul sebagai produk pengembangan dilakukan oleh pakar media pembelajaran dan pakar kimia. Uji kepraktisan modul berupa uji keterbacaan dilakukan oleh mahasiswa yang menjadi subjek penelitian. Uji keterbacaan dilakukan berdasarkan uji perorangan dan uji kelompok kecil. Setelah mendapatkan masukan atau perbaikan dari validator dan mahasiswa berkaitan dengan kevalidan dan kepraktisan, dilakukan revisi terhadap modul. Selanjutnya, hasil revisi dilakukan uji lapangan untuk melihat efektivitas modul yang dikembangkan. Uji efektivitas dilakukan berupa uji perorangan dan uji kelompok kecil dengan desain one group pretest-posttest. Selanjutnya dilakukan survei untuk melihat respon siswa terhadap modul yang dikembangkan. Kegiatan pengembangan ini dilakukan dengan mengadakan pengamatan proses pembelajaran dan tes hasil belajar. Hasil kegiatan ini adalah bukti mengenai tingkat kelayakan modul sebagai panduan belajar mandiri.

Data yang dikumpulkan dalam penelitian ini terdiri dari data validitas dan keterbacaan modul serta respon dan hasil belajar mahasiswa setelah penggunaan modul. Jenis dan teknik pengumpulan data dalam penelitian ini adalah sebagai berikut. Validasi modul yang dihasilkan berdasarkan penilaian pakar media pembelajaran dan pakar Kimia. Hasil tes setelah penggunaan modul digunakan sebagai data hasil belajar. Angket respon mahasiswa terhadap modul yang digunakan untuk melihat respon siswa setelah penggunaan modul.

Teknik analisis data dilakukan secara deskriptif kuantitatif. Tingkat validitas modul dinilai oleh pakar dengan mengacu pada lembar validasi yang telah dikembangkan oleh peneliti yang meliputi aspek kesesuaian, keakuratan, kemutakhiran dan kemenarikan materi serta penyajian dan kebahasaan. Penilaian lembar validasi dilakukan dengan memberikan skor 4, 3, 2, dan 1 pada aspek penilaian dengan kategori seperti yang disajikan pada Tabel 1.

Tabel 1. Pedoman Penskoran Lembar Penilaian Validasi

\begin{tabular}{lc}
\hline \multicolumn{1}{c}{ Kategori } & Skor \\
\hline Sangat baik/sangat sesuai & 4 \\
Baik/sesuai & 3 \\
Kurang baik/kurang sesuai & 2 \\
Tidak baik/tidak sesuai & 1
\end{tabular}


Jurnal Inovasi Pendidikan IPA, 5 (1), 2019 - 58

Rilia Iriani, Anna Herlina, Yudha Irhasyuarna, Rahmat Eko Sanjaya

Validitas produk yang dikembangkan diukur dengan menghitung skor rata-rata aspek validasi untuk tiap-tiap pakar. Penilaian oleh pakar pada setiap aspek kemudian dirata-ratakan dan selanjutnya dicocokan dengan tabel kriteria penilaian yang mengacu pada Widoyoko (2013). Skor minimal ideal dalam lembar validasi adalah 1 dan skor maksimal ideal adalah 4. Sehingga pedoman penilaian kelayakan modul dapat dikembangkan menjadi tabel kriteria validitas produk, seperti yang disajikan pada Tabel 2 . Apabila bahan ajar terdapat dalam kriteria baik dan sangat baik, berarti bahan ajar tersebut sudah valid dan dapat diujicobakan.

Tabel 2. Kriteria Validitas Produk

\begin{tabular}{cl}
\hline Interval & \multicolumn{1}{c}{ Kategori } \\
\hline$X>3,4$ & Sangat baik (SB) \\
$2,8<X \leq 3,4$ & Baik (B) \\
$2,2<X \leq 2,8$ & Cukup baik (CB) \\
$1,6<X \leq 2,2$ & Kurang (K) \\
$X \leq 1,6$ & Sangat kurang (SK) \\
\hline
\end{tabular}

Data hasil angket uji keterbacaan dianalisis dengan menggunakan rumus seperti Rumus 1 .

Skor $=\frac{\text { Jumlah } \text { skor } \text { yang didapat }}{\text { Jumlah pernyataan }}$

Rata-rata skor hasil uji keterbacaan modul dilakukan interpretasi. Interpretasi skor tanggapan uji keterbacaan mahasiswa terhadap modul yang dikembangkan mengacu pada pedoman kriteria tanggapan mahasiswa seperti pada Tabel 3.

Tabel 3. Pedoman Kriteria Skor Uji Keterbacaan

\begin{tabular}{cl}
\hline \multicolumn{1}{c}{ Skor } & \multicolumn{1}{c}{ Keterangan } \\
\hline $3,25<$ skor $<4$ & Sangat baik \\
$2,5<$ skor $<3,25$ & Baik \\
$1,75<$ skor $<2,5$ & Kurang baik \\
$1<$ skor $<1,75$ & Sangat kurang baik \\
\hline
\end{tabular}

(Wikhdah, Sumarti, \& Wardani, 2015)

Angket respon diberikan setelah selesai pembelajaran. Penskoran angket respon menggunakan skala Likert dengan memberikan skor dengan rentang 1-5 untuk pernyataan positif, skor 1 untuk "sangat tidak setuju", 2 untuk "tidak setuju", 3 untuk "ragu-ragu", 4 untuk "setuju", dan 5 untuk "sangat setuju". Hasil respon diolah dan dicocokkan dengan kriteria penentuan skala respon untuk 12 pernyataan yang mengacu pada Tabel 4.

Hasil respon siswa cukup, kurang atau sangat kurang, berarti modul yang dikembangkan sangat sulit bagi mahasiswa sehingga perlu perbaikan terhadap modul. Modul dikatakan praktis untuk digunakan jika hasil respon mahasiswa pada kategori baik atau sangat baik.

Tabel 4. Pedoman kategori respon mahasiswa

\begin{tabular}{cl}
\hline Persentase $(\%)$ & \multicolumn{1}{c}{ Kategori } \\
\hline $84,01-100$ & Sangat baik \\
$68,01-84$ & Baik \\
$52,01-68$ & Cukup \\
$36,01-52$ & Kurang \\
$20,00-36$ & Sangat kurang \\
\hline
\end{tabular}

Analisis hasil belajar bertujuan untuk mengetahui efektivitas modul yang dikembangkan. Jumlah jawaban benar dari hasil tes mahasiswa dianalisis secara deskriptif untuk mengetahui tingkat keberhasilan hasil belajar menggunakan teknik persentase. Data hasil tes yang diperoleh kemudian dikonversi dengan mengacu pada pedoman hasil belajar yang disajikan Tabel 5 .

Tabel 5. Pedoman Kategori Hasil Belajar Mahasiswa

\begin{tabular}{cl}
\hline Tingkat keberhasilan & \multicolumn{1}{c}{ Kategori } \\
\hline $90 \leq \mathrm{x}$ & A (Sangat Tinggi) \\
$80 \leq \mathrm{x}<90$ & B (Tinggi) \\
$70 \leq \mathrm{x}<80$ & C (Sedang) \\
$60 \leq \mathrm{x}<70$ & D (Rendah) \\
$\mathrm{x}<60$ & E (Sangat Rendah) \\
\hline
\end{tabular}

(Ratumanan \& Laurens, 2003)

Hasil belajar juga dilihat nilai indeks gain yang diperoleh dari pretest dan posttest. Indeks gain dapat dihitung dengan menggunakan Rumus 2.

$$
N \text {-gain }=\frac{\text { skor post test-skor pretest }}{\text { skor maksimum-skor pretest }}
$$

Tabel 6. Kategori Indeks Gain Hasil Pretest dan Posttest

\begin{tabular}{|c|c|}
\hline Indeks Gain & Kategori \\
\hline$g \geq 0,70$ & Tinggi \\
\hline $0,30<g<0,70$ & Sedang \\
\hline$g<0,30$ & Rendah \\
\hline
\end{tabular}

(Hake, 1999)

\section{HASIL DAN PEMBAHASAN}

Produk pengembangan yang dihasilkan dalam penelitian adalah modul Problem-Based Learning (PBL) (http://eprints.ulm.ac.id/6523/) berbasis lahan basah untuk mahasiswa Program Studi Pendidikan Kimia FKIP ULM. Keunggulan dari modul PBL berbasis lahan basah sebagai bahan ajar adalah menjadikan mahasiswa lebih dekat dan mampu menyelesaikan permasalahan lingkungan di kawasan lahan basah. Desain penelitian pengembangan mengacu pada model 
pengembangan 4-D oleh Thiagarajan et al., (1974). Model pengembangan yang dilakukan hanya 3-D, karena pada tahap disseminate atau penyebaran membutuhkan waktu yang lama dan memerlukan SDM yang banyak serta penelitian ini hanya sebatas menghasilkan produk prototipe karena tidak ada proses packaging, diffusion dan adoption. Sehingga penelitian hanya sampai pada simpulan kelayakan modul berdasarkan kriteria validitas, keterbacaan, efektivitas serta respon mahasiswa terhadap modul berbasis lahan basah yang dikembangkan.

Langkah awal dalam pengembangan modul PBL berbasis lahan basah adalah melakukan analisis mahasiswa, analisis konsep dan analisis tugas yang terdapat pada perkuliahan Kimia Lingkungan Lahan Basah. Hasil wawancara terhadap mahasiswa yang merupakan penelitian pendahuluan dalam pengembangan ini menyatakan bahwa diperlukan suatu bahan ajar yang sesuai dengan kurikulum Kimia Lingkungan Lahan Basah. Pembelajaran yang hanya menggunakan buku teks Kimia Lingkungan dianggap terlalu luas dan belum dapat mengakomodasi peran lingkungan lahan basah dalam pembelajaran.

Hasil wawancara lainnya berkaitan dengan kebutuhan modul pembelajaran berbasis lingkungan lahan basah juga menunjukkan bahwa mahasiswa menginginkan adanya bahan ajar yang dapat digunakan dengan mudah dan berdasarkan pada permasalahan nyata atau otentik. Permasalahan nyata tersebut merupakan permasalahan yang terjadi di lingkungan sekitar dan dapat diatasi dengan menggunakan teori-teori yang telah dipelajari. Wawancara ini menginginkan agar dengan bahan ajar tersebut, mahasiswa terlibat dalam mengatasi persoalan yang terjadi dan persoalan tersebut bersifat nyata atau praktis dan tidak hanya bersifat teoritis.

Berdasarkan hasil wawancara tersebut di atas, diketahui bahwa mahasiswa menginginkan adanya bahan ajar/modul pada mata kuliah Kimia Lingkungan Lahan Basah yang mudah dipelajari dan menghadapkan mahasiswa pada permasalahan-permasalahan otentik yang terjadi di lingkungan. Mahasiswa beranggapan bahwa pembelajaran secara langsung berdasarkan permasalahan nyata lebih berkesan dan mudah diingat. Tanggapan mahasiswa atas survei yang dilakukan memberi arti bahwa pembelajaran yang berhadapan langsung dengan masalah nyata akan memberikan pembelajaran yang bermakna bagi mahasiswa. Tafsiran ini sesuai dengan pernyataan Hmelo-Silver \& Barrows (2006) dan HmeloSilver (2004) yang menyatakan bahwa pembel- ajaran berbasis masalah selain membelajarkan pengetahuan, juga membelajarakan strategi untuk mengatasi masalah, sehingga pembelajaran lebih bermakna.

Pola pembelajaran yang sesuai untuk mengatasi pembelajaran yang menghadapkan pada masalah otentik adalah pembelajaran yang berbasis masalah (problem-based learning). Mahasiswa dihadapkan langsung pada masalah nyata yang terjadi di lingkungan sekitar. Pada saat menghadapi masalah tersebut, mahasiswa dapat melakukan elaborasi atas pengetahuan yang telah dimiliki untuk mengatasi permasalahan tersebut. Sehingga modul kimia lingkungan yang dikembangkan adalah modul kimia lingkungan lahan basah berdasarkan pada pembelajaran berbasis masalah.

Rancangan awal modul yang dikembangkan menyesuaikan dengan kurikulum yang dimiliki oleh Program Studi Pendidikan Kimia FKIP ULM dan memasukkan pembahasan mengenai lingkungan lahan basah sebagai pokok utama pembelajaran. Misalnya, pada topik pencemaran air, maka kajian teori dan pemasalahan yang disajikan adalah pencemaran air pada lingkungan atau kawasan lahan basah. Tugastugas yang dikerjakan mahasiswa pun mengacu pada lahan basah dan tugas tersebut berstruktur permasalahan yang memerlukan tahapan-tahapan tertentu dalam penyelesaiannya.

Rancangan modul yang akan dikembangkan berfokus pada permasalahan yang dihadapi oleh mahasiswa. Permasalahan tersebut yang harus diselesaikan oleh mahasiswa dan menjadi landasan utama dalam penyusunan materi pada modul. Pada akhirnya mahasiswa akan melakukan serangkaian kegiatan untuk mengatasi permasalahan tersebut, yaitu berupa pembelajaran di lapangan. Untuk fokus dalam pengembangan modul, topik yang dikembangkan dalam modul ini adalah sebagian dari kurikulum yang diajarkan dalam kurikulum Kimia Lingkungan Lahan Basah dalam satu semester, yaitu hanya pada topik pencemaran air dan identifikasi ceramaran air di kawasan lahan basah. Rancangan awal ini kemudian ditentukan kelayakannya berdasarkan pada hasil validasi oleh pakar, kepraktisan dalam hal keterbacaan dan respon mahasiswa serta efektivitas modul.

Pembelajaran di lapangan, yaitu mahasiswa melakukan penelitian di Desa Tanipah, Kecamatan Aluh-Aluh, Kabupaten Banjar. Penelitian dilakukan untuk mengetahui kualitas air sungai di Desa Tanipah. Masyarakat di Desa Tanipah tinggal di sepanjang aliran sungai dan 
menjadikan sungai sebagai sumber kehidupan. Transportasi dan keperluan lainnya menggunakan aliran sungai. Hasil penelitian dari kualitas air di Desa Tanipah menunjukkan bahwa air sungai masuk dalam kategori kelas 3, yaitu hanya digunakan sebagai pengairan dan bukan untuk konsumsi (Sanjaya \& Iriani, 2018). Pembelajaran yang langsung menuju ke masyarakat dan lingkungan merupakan salah satu tujuan utama dari dikembangkannya modul ini.

Validitas modul dinilai oleh 4 orang pakar yang memiliki disiplin ilmu bidang media pembelajaran dan kimia. Penilaian dan saran oleh ahli digunakan sebagai bahan untuk perbaikan modul yang dikembangkan. Hasil uji validitas modul dari ahli disajikan pada Tabel 7.

Tabel 7. Hasil uji validitas modul

\begin{tabular}{lcccc}
\hline \multirow{2}{*}{ Aspek } & \multicolumn{4}{c}{ Validasi Pakar } \\
\cline { 2 - 5 } \multicolumn{1}{c}{ I } & II & III & IV \\
\hline Kesesuaian materi & SB & SB & SB & SB \\
Keakuratan materi & SB & B & B & B \\
Kemutakhiran materi & SB & B & B & B \\
Kemenarikan materi & SB & B & B & B \\
Penyajian & SB & B & B & B \\
Kebahasaaan & SB & B & B & B \\
\hline
\end{tabular}

Semua ahli memberikan penilaian dengan kategori minimal baik. Berdasarkan hasil validasi ini, terlihat bahwa modul PBL berbasis lingkungan lahan basah yang dikembangkan telah memenuhi syarat kelayakan, yaitu berada pada kategori minimal 'baik'.

Uji validitas oleh pakar dilakukan sebagai uji awal tahap pengembangan setelah tahap perencanaan produk. Pakar yang terlibat dalam uji validitas modul PBL berbasis lahan basah terdiri dari 4 orang pakar yang terdiri atas dua pakar media pembelajaran dan dua pakar kimia. Empat orang pakar diminta untuk menilai aspek kelayakan isi modul berkaitan dengan permasalahan lingkungan pada kawasan lahan basah, kelayakan penyajian berupa tampilan modul dan aspek kebahasaan. Setiap aspek yang dinilai, secara kuantitatif mendapatkan rata-rata skor 3,25 dan berada pada kategori "baik". Secara kualitatif terdapat beberapa perbaikan yang dilakukan untuk modul PBL berbasis lahan basah berdasarkan saran dari pakar. Setiap aspek tersebut mendapatkan saran dari pakar untuk dilakukan perbaikan dan penambahan, sehingga dapat dihasilkan modul yang layak untuk digunakan dalam perkuliahan Kimia Lingkungan Lahan Basah.

Aspek-aspek yang termasuk dalam kelayakan materi memiliki empat indikator penilaian yaitu kesesuaian materi dengan $\mathrm{KI}$ dan $\mathrm{KD}$, keakuratan materi, kemutakhiran materi dan kemenarikan materi. Pada setiap indikator terdapat beberapa butir penilaian untuk menilai kelayakan isi modul. Pertama, kesesuaian materi dengan kurikulum dan capaian pembelajaran lulusan (CPL) mata kuliah Kimia Lingkungan Lahan Basah yang telah ditetapkan. Kedua, keakuratan materi mencangkup keakuratan konsep, contoh, tugas, gambar, diagram dan ilustrasi lain berkaitan dengan materi pencemaran air dalam konteks di lingkungan lahan basah. Ketiga, kemenarikan materi berupa pendukung materi pembelajaran yang berkaitan dengan terakomodasinya penalaran, komunikasi yang terjadi, penerapan, kemenarikan, atau pun penambahan informasi lain untuk memperjelas konsep yang disajikan. Keempat, kemutakhiran materi yang berhubungan dengan kesesuaian materi dengan perkembangan ilmu terbaru berkaitan dengan lingkungan lahan basah.

Aspek kelayakan penyajian memiliki empat indikator penilaian yaitu teknik penyajian, pendukung penyajian, penyajian pembelajaran dan kelengkapan penyajian. Setiap indikator memiliki butir penilaian untuk menilai kelayakan penyajian modul. Pertama, teknik penyajian adalah konsistensi sistematika penyajian dan keruntutan penyajian dalam modul. Kedua, pendukung penyajian seperti kata pengantar, karakteristik modul, daftar isi, kesimpulan, dan daftar pustaka. Ketiga, penyajian pembelajaran adalah penyajian materi yang melibatkan mahasiswa untuk bersifat interaktif dan partisipatif. Keempat, kelengkapan penyajian seperti bagian pendahuluan, isi dan penutup sesuai dengan tujuan modul dan disusun sesuai dengan fakta, data serta teori.

Pada aspek kelayakan bahasa atau kebahasaan terdiri dari enam indikator penilaian yaitu lugas, komunikatif, dialogis, dan interaktif, kesesuaian dengan tingkat perkembangan mahasiswa, keruntutan dan keterpaduan alur pikir, serta penggunaan istilah, simbol atau ikon. Pakar memberikan penilaian pada setiap butir pernyataan dengan ketentuan yang menyatakan kriteria kesesuaian komponen isi dalam modul yang dikembangkan. Butir-butir penilaian yang dinilai terdiri dari sangat kurang baik, kurang baik, baik dan sangat baik serta untuk perbaikannya diberikan saran dalam bentuk deskriptif. Adapun saran dari masing-masing pakar adalah memperdalam materi modul yang dikembangkan, memperkaya modul dengan konsep lahan basah, memperbaiki tujuan pembelajaran dan soal-soal yang masih belum sesuai dengan indikator, memperbaiki 


\section{Jurnal Inovasi Pendidikan IPA, 5 (1), 2019 - 61}

Rilia Iriani, Anna Herlina, Yudha Irhasyuarna, Rahmat Eko Sanjaya

bahasa dan kosa kata, serta tulisan yang belum sempurna.

Penilaian pakar terhadap modul yang dikembangkan ditindaklanjuti dengan melakukan revisi modul. Beberapa perbaikan yang dilakukan terhadap modul yang dikembangkan tersaji pada Gambar 2. Sebelumnya tampilan deskripsi modul terlihat monoton dan kaku, sehingga dilakukan perbaikan dari segi tampilan serta perbaikan kalimat dari deskripsi modul seperti terlihat pada Gambar 3.

Kepraktisan modul dilihat berdasarkan dua aspek pengujian yaitu uji keterbacaan dan respon mahasiswa setelah menggunakan modul PBL berbasis lahan basah. Hasil uji keterbacaan perorangan dan kelompok kecil masing-masing memiliki skor rata-rata 3,0 dan secara kualitatif berada pada kategori "baik". Selain memperoleh data skor uji keterbacaan, lembar angket keterbacaan juga menyediakan kolom saran untuk perbaikan modul. Saran-saran tersebut menjadi masukan bagi peneliti dalam memperbaiki modul yang dikembangkan untuk mencapai tingkat kepraktisan semaksimal mungkin.
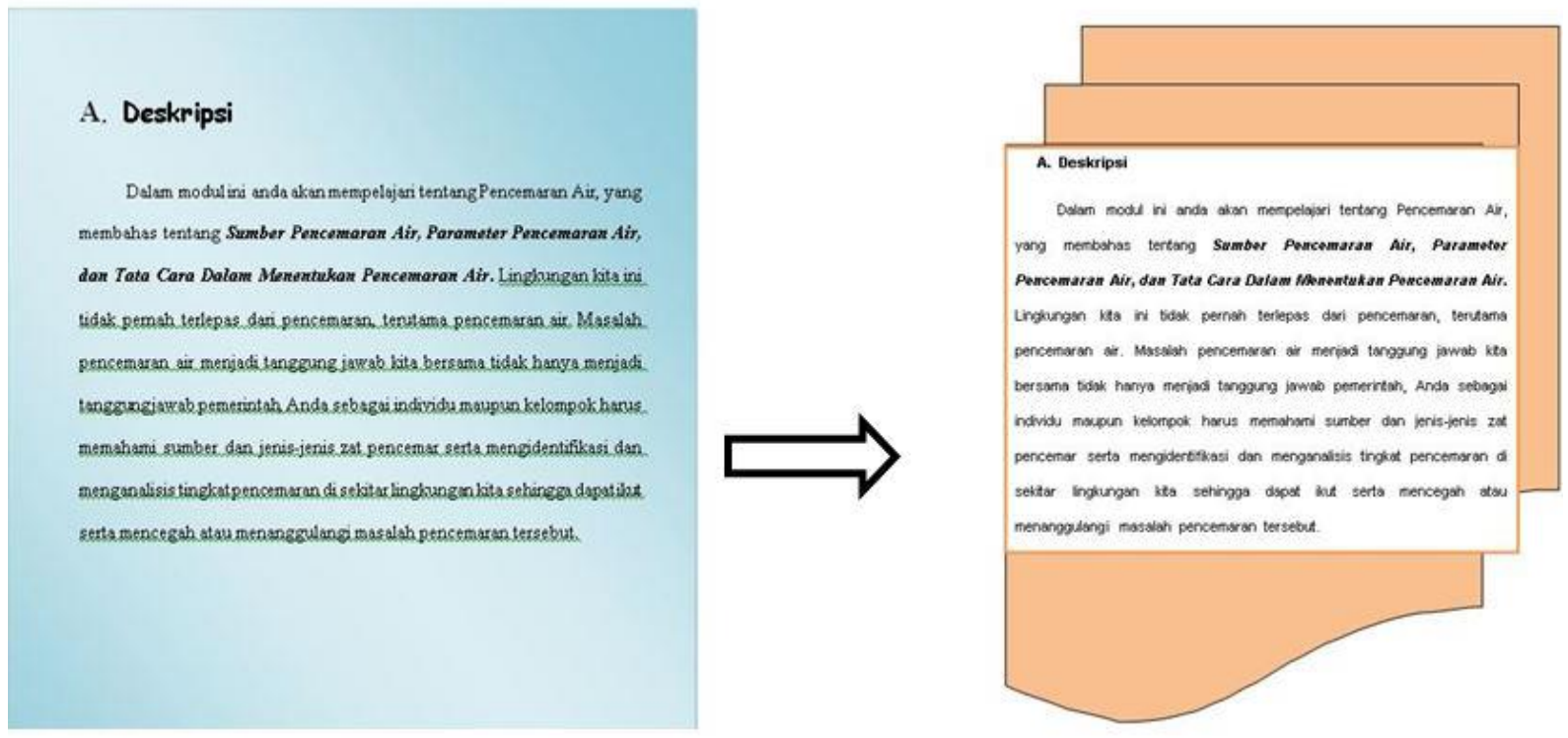

Gambar 2. Perubahan Tampilan Deskripsi Modul

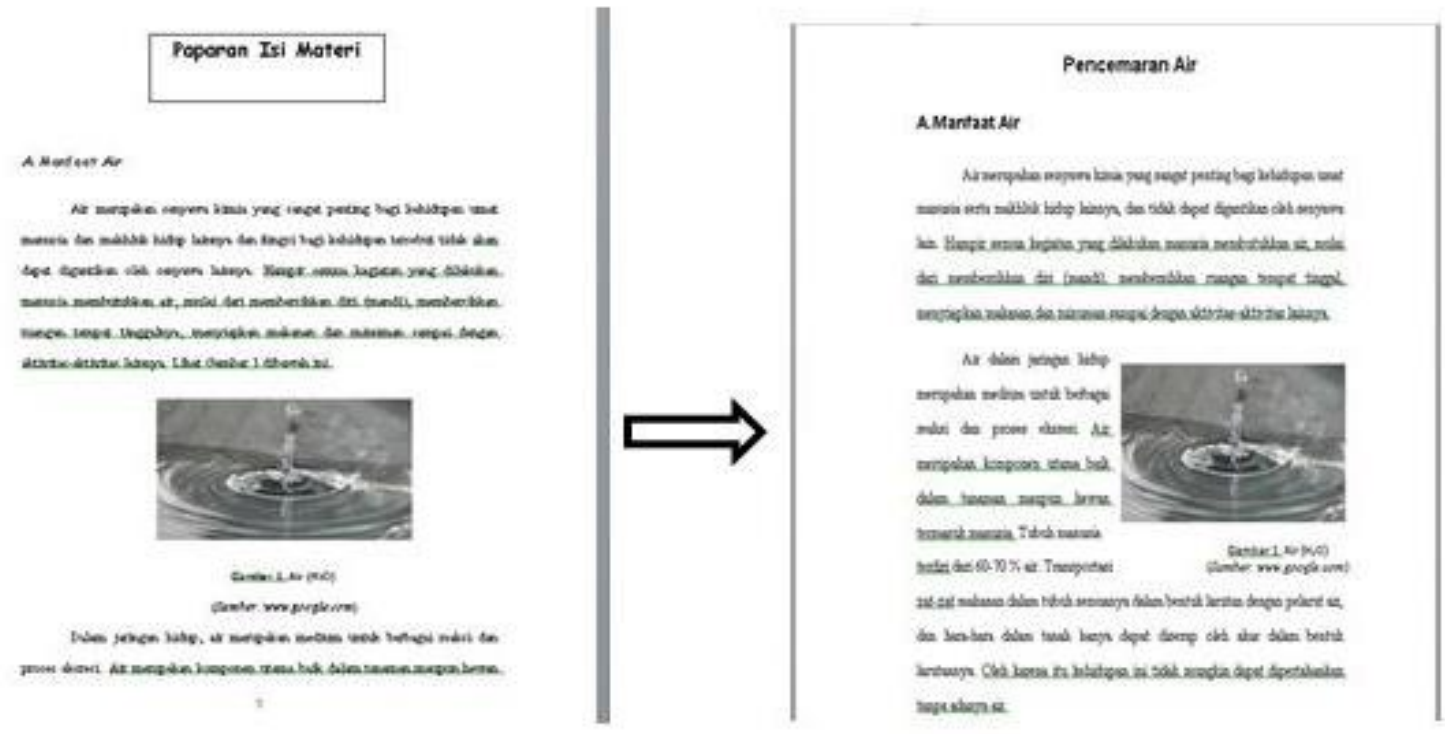

Gambar 3. Perubahan Tata Letak Isi Modul 
Jurnal Inovasi Pendidikan IPA, 5 (1), 2019 - 62

Rilia Iriani, Anna Herlina, Yudha Irhasyuarna, Rahmat Eko Sanjaya
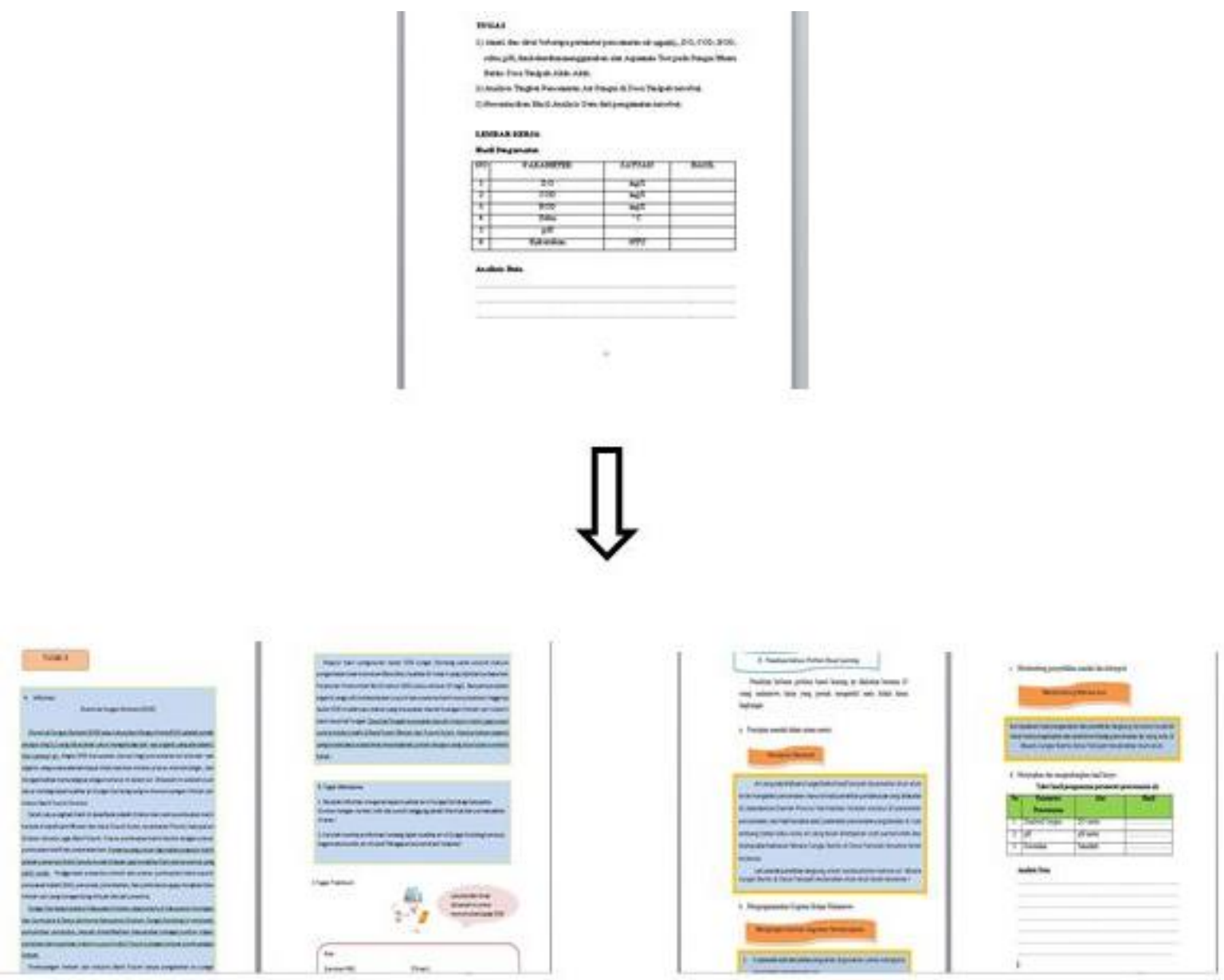

Gambar 4. Perbaikan Deskripsi Tugas dan Tampilan Penugasan

Uji kepraktisan modul berupa uji keterbacaan, terdapat 10 pernyataan positif untuk menilai keterbacaan modul. Sepuluh pernyataan tersebut secara garis besar berisi tentang tampilan modul, ketajaman dan tata letak gambar, kerunutan materi yang disajikan, kemudahan materi untuk dipahami, keberadaan istilah yang dapat diartikan, dan tidak ada kalimat yang menimbulkan makna ganda. Hasil pengolahan data terhadap angket keterbacaan terdapat penialain bahwa modul yang dikembangkan memiliki istilah yang belum dipahami oleh mahasiswa dan tidak ada penjelasan terhadap istilah tersebut. Permasalahan tersebut diatasi dengan penjelasan terhadap istilah yang mucul dalam modul. Istilah-istilah yang muncul dalam modul berkaitan dengan istilah atau indikator untuk menentukan kualitas air. Bahasa untuk menjelaskan istilah tersebut dikemas sedemikian rupa sehingga mudah dipahami oleh mahasiswa yang tidak berlatar belakang ilmu lingkungan.

Respon mahasiswa merupakan data pendukung lain yang digunakan untuk melihat kepraktisan modul yang dikembangkan. Angket respon mahasiswa berisikan 12 butir pernyataan.
Angket respon diberikan setelah mahasiswa melakukan posttest. Angket respon mahasiswa secara umum berisi informasi tentang motivasi, kemudahan belajar, ketertarikan dalam belajar, menjadikan mahasiswa terlibat aktif dalam pembelajaran, dan kesesuaian modul dengan lingkungan sekitar. Hasil angket respon menunjukkan bahwa rata-rata respon mahasiswa pada uji perorangan dan kelompok kecil berturut-turut adalah adalah $78,33 \%$ dan $71,67 \%$, yang artinya modul yang dikembangkan berada dalam kategori "baik".

Respon yang diberikan mahasiswa terhadap modul PBL berbasis lahan basah dinyatakan membantu mahasiswa memahami kondisi lingkungan sekitar. Kemasan modul yang mengajak mahasiswa langsung praktik ke lingkungan lahan basah, menjadikan modul ini dapat menuntun mahasiswa untuk memahami kondisi lingkungan lahan basah. Lingkungan lahan basah yang terdiri atas perairan dapat menjadi sumber pembelajaran yang menarik, khususnya untuk materi cemaran air. Selain itu, pembelajaran yang langsung praktik di lingkungan lahan basah menjadikan mahasiswa lebih sadar dan peduli terhadap 
lingkungan lahan basah. Kepedulian terhadap lingkungan sebagai hasil pengembangan modul pembelajaran PBL ini didukung oleh Primarinda, Prayitno \& Maridi (2014) bahwa pengembangan modul berorientasi PBL pada materi pencemaran efektif memberdayakan sikap peduli lingkungan peserta didik.

Pada uji coba kelompok kecil, hasil respon mahasiswa memberikan nilai tertinggi untuk tiga pernyataan dari dua belas pernyataan. Tiga pernyataan tersebut berisi (1) modul PBL memudahkan dalam mengingat materi perkuliahan, (2) wacana yang terdapat dalam modul PBL dapat mendorong untuk terlibat pada aktivitas pemecahan masalah, (3) modul PBL membantu dalam menentukan adanya pencemaran air yang ada di lingkungan sekitar. Yarid \& Ariswan (2016), Lestari \& Projosantoso (2016) dan Utaminingsih, Rahayu \& Andini (2018) mengungkapkan bahwa pembelajaran dan perangkatnya yang menggunakan model PBL dapat meningkatkan hasil dan minat belajar. Hasil ini senada dengan respon yang diberikan oleh mahasiswa terhadap modul Kimia Lingkungan Lahan Basah yang dikembangkan bahwa dengan modul tersebut dapat memudahkan mereka untuk mengingat dan berdampak pada peningkatan hasil belajar.

Salah satu poin yang menjadi sorotan dari hasil respon mahasiswa adalah bahwa dengan modul yang dikembangkan mereka merasa terdorong untuk terlibat dalam aktivitas pemecahan masalah. Aktivitas pemecahan masalah tidak hanya melibatkan konten dari pengetahuan yang dipelajari tetapi juga strategi dalam penggunaan konten tersebut untuk mengatasi permasalahan yang bersifat otentik atau nyata (Tatar \& Oktay, 2011; Savery, 2006; Hmelo-Silver, 2004). Dorongan yang dirasakan oleh mahasiswa untuk terlibat karena yang mereka hadapi adalah permasalahan otentik yang terjadi disekitar mereka dan dirasakan secara langsung. Permasalahan otentik yang menyajikan kasus komplek dapat merangsang mahasiswa untuk berpikir lebih dalam dan berujung pada rasa ingin tahu yang lebih dalam untuk mengatasi permasalahan yang dihadapi (Günter \& Alpat, 2017; Hung, Jonassen \& Liu, 2008).

Pernyataan lainnya dari angket respon mahasiswa adalah pernyataan yang berbunyi, modul pencemaran air berbasis problem-based learning $(P B L)$ untuk mahasiswa mata kuliah kimia lingkungan membuat saya merasa tidak bosan dalam proses belajar mengajar di kelas. Pernyataan ini memiliki persentase terendah dibandingkan dengan sebelas pernyataan respon lainnya. Hal ini bermakna bahwa modul yang dikembangkan belum dapat menghilangkan kebosanan mahasiswa dalam mempelajari materi. Analisis lebih lanjut atas repon ini memberikan hasil bahwa mahasiswa lebih tertarik dengan media pembelajaran yang dapat diakses dengan mudah, kapan saja dan dimana saja. Mahasiswa merasa pembelajaran yang disajikan dalam bentuk aplikasi di smartphone akan lebih menarik dan tidak membuat bosan.

Mahasiswa lebih banyak menghabiskan waktu di depan smartphone yang terintegrasi dengan internet dibandingkan dengan buku teks (Ng, Hassan, Nor \& Malek, 2017). Sehingga mahasiswa tidak terasa bosan jika pembelajaran disajikan berbasis pada smartphone. Menyajikan pembelajaran dengan menggunakan media yang akrab dengan mahasiswa memungkinkan untuk mengurangi tingkat kebosanan mahasiswa dalam belajar. Hal ini dinyatakan oleh Kumar (2011) bahwa mahasiswa menggunakan smartphone untuk mencari informasi tambahan perkuliahan secara online melalui $e$-book dan sumber bacaan lainnya. Selain itu, Mtega, Bernard, Msungu dan Sanare (2012) menyatakan bahwa smartphone yang digunakan oleh mahasiswa tidak hanya berisi aplikasi sederhana seperti telpon dan sms, tetapi juga aplikasi penunjang pembelajaran seperti GPS, kamera, voice calls, email, Google drive dan sebagainya, yang digunakan untuk membuat, mengunggah dan mengunduh serta saling bagi sumber informasi pembelajaran lainnya. Hal ini menunjukkan bahwa mahasiswa merasa lebih tertarik jika pembelajaran dilakukan dengan menggunakan atau berbasis smartphone. Oleh karena itu, ke depannya, modul yang dikembangkan ini akan dikonversi ke dalam modul berbasis aplikasi di smartphone.

Efektivitas modul dilihat dari pemahaman mahasiswa terhadap materi pencemaran air di lingkungan lahan basah. Pemahaman mahasiswa dilihat dari kemampuan mahasiswa untuk menjawab soal evaluasi tentang materi pencemaran air di lingkungan lahan basah. Evaluasi dilakukan pada akhir kegiatan pembelajaran yang menggunakan modul PBL berbasis lahan basah. Sebelum dilakukan pembelajaran dengan menggunakan modul yang dikembangkan, dilakukan tes awal (pretest) untuk mengetahui kemampuan awal mahasiswa terhadap materi pencemaran air. Setelah dilakukan pembelajaran menggunakan modul yang dikembangkan, mahasiswa mengerjakan tes akhir (posttest) untuk mengetahui kemampuan akhir mahasiswa. Soal pretest dan posttest yang diberikan sebanyak 5 buah soal 
pilihan ganda dan 5 buah soal uraian. Hasil pretest uji perorangan adalah 25,0 atau berkategori $\mathrm{E}$ (Sangat Rendah). Sedangkan, setelah dilakukan pembelajaran menggunakan modul yang dikembangkan nilai posttest mahasiswa meningkat menjadi 93,8 atau berkategori A (Sangat Tinggi). Perhitungan $\mathrm{N}$-gain untuk mengetahui peningkatan hasil belajar uji coba perorangan diperoleh hasil sebesar 0,9 yang berarti pembelajaran telah berjalan dengan baik dengan kategori tinggi.

Pada kegiatan pembelajaran untuk uji coba perorangan terdapat empat indikator pembelajaran. Indikator pertama tentang merumuskan sumber dan jenis-jenis pencemaran air. Indikator kedua berkaitan dengan pengukuran parameter pencemaran air. Indikator tiga yaitu analisis terjadinya pencemaran air. Indikator keempat yaitu memberikan solusi penanggulangan pencemaran air. Keempat indikator tersebut selain menjadi indikator dalam pembelajaran, juga menjadi indikator dalam evaluasi pemahaman mahasiswa. Kompetensi mahasiswa dalam memahami materi pencemaran air terlihat dari kemampuan mahasiswa dalam menjawab soal evaluasi tersebut.

Hasil posttest uji coba perorangan menunjukkan bahwa nilai yang diperoleh mahasiswa pada indikator pertama, kedua dan keempat, mendapatkan nilai sempurna yaitu 100 (A). Sementara itu, pada indikator ketiga, nilai yang didapat oleh mahasiswa hanya 75 (C). Hal ini dapat dikatakan bahwa mahasiswa mampu menganalisis terjadinya pencemaran air, walaupun dalam menganalisis terjadinya pencemaran air mahasiswa masih ada sedikit kesalahan, akan tetapi jawaban mahasiswa pada wacana tentang adanya pencemaran air cukup baik dan mampu mengkonstruksi pemahaman pribadi mereka dengan permasalahan pencemaran air yang ada di wacana.

Uji coba kelompok kecil diberikan terhadap 8 orang mahasiswa dengan memberikan pretest dan posttest sebanyak 5 buah soal pilihan ganda dan 5 buah soal uraian. Uji coba lapangan terbatas atau uji coba kelompok kecil, diperoleh rata-rata hasil pretest adalah 19,9 atau berkategori E (Sangat Rendah). Setelah dilakukan pembelajaran menggunakan modul yang dikembangkan rata-rata nilai posttest mahasiswa meningkat menjadi 92,6 atau berkategori A (Sangat Tinggi). Hasil $N$-gain pretest dan posttest uji coba kelompok kecil diperoleh hasil sebesar 9,0 dan hasil ini menunjukkan bahwa terjadi peningkatan yang cukup tinggi terhadap pemahaman mahasiswa pada saat sebelum dan sesudah diberikan perlakukan dengan menggunakan modul PBL berbasis lahan basah. Indikator yang digunakan dalam uji coba kelompok kecil sama dengan indikator yang digunakan untuk uji coba perorangan yaitu dengan menggunakan empat indikator pembelajaran dengan topik pencemaran air.

Pembelajaran berbasis masalah atau problem-based learning telah memberikan hasil yang positif berkaitan dengan prestasi pebelajar, baik siswa maupun mahasiswa. Media dan bahan pembelajaran yang dikembangkan dengan menggunakan PBL sebagai basis pengembangan terbukti efektif dalam meningkatkan prestasi pebelajar. Media atau bahan pembelajaran berbasis PBL yang dikembangkan memiliki hasil efektif untuk meningkatkan motivasi dan berpikir kritis siswa (Puspadewi \& Syahmani, 2016; Sari \& Sugiyarto, 2015; Wati, Rusmansyah \& Sholahuddin, 2014) serta menumbuh-kembangkan atmosfer kebebasan intelektual (Sutrisno, 2011).

Peningkatan hasil belajar yang ditunjukkan dengan besarnya nilai $N$-gain yang diperoleh, memberikan arti bahwa pembelajaran dengan menggunakan modul PBL memiliki kemampuan dalam meningkatkan kemampuan analitis dan pemahaman mahasiswa terhadap materi kimia lingkungan yang dipelajari. Modul PBL berbasis lahan basah menuntut mahasiswa untuk terjun langsung ke lapangan guna mengatasi permasalahan yang ada. Permasalahan yang disajikan dalam modul ini dan harus diatasi oleh mahasiswa adalah pencemaran air di desa Tanipah. Mahasiswa dilibatkan langsung untuk mengindentifikasi serta memberikan solusi terhadap pencemaran air yang terjadi. Proses pembelajaran yang berkaitan langsung dengan kehidupan sehari-hari ini lah yang menjadikan pembelajaran PBL menjadi menarik dan memberikan efektivitas yang baik dalam pembelajaran (Aidoo, Boateng, Kissi \& Ofori, 2016; Ayyildiz \& Tarhan, 2017; Günter, Akkuzu \& Alpat, 2017; Yew \& Goh, 2016)

Penelitian pengembangan modul PBL berbasis lahan basah, setelah melewati tahap pendefinisian, perencanaan dan pengembangan, diperoleh beberapa temuan yang dapat menjadi daya tarik dalam modul ini. Penggunaan modul PBL berbasis lahan basah untuk materi pencemaran air, membuat mahasiswa bersemangat untuk mengikuti pembelajaran, terutama saat terjun langsung ke lapangan untuk mengidentifikasi adanya pencemaran air di sungai. Mahasiswa sangat antusias saat mengukur parameter pencemaran air menggunakan alat yang disediakan yaitu sansidist, $\mathrm{pH}$ meter, dan DO meter. Modul 
ini menghadapkan mahasiswa pada permasalahan-permasalahan yang otentik dan terdapat di lingkungan sekitar, sehingga mahasiswa dapat belajar secara nyata tentang pencemaran air serta cara mengatasinya.

Secara garis besar, modul PBL berbasis lahan basah yang dikembangkan untuk materi pencemaran air pada mata kuliah kimia lingkungan lahan basah mempunyai pengaruh dalam meningkatkan hasil belajar mahasiswa atau meningkatnya kemampuan pemahaman mahasiswa. Selain itu, mahasiswa memiliki wawasan terhadap lingkungan lahan basah yang merupakan keunggulan lokal di Kalimantan Selatan. Annafi \& Agustina (2018) dalam publikasinya menyatakan hal yang senada bahwa model PBL yang mengangkat kearifan dan potensi lokal selain mampua meningkatkan hasil belajar, juga dapat menumbuhkan sikap dan karakter mahasiswa terhadap lingkungan sekitar.

\section{SIMPULAN}

Berdasarkan hasil analisis data dapat disimpulkan bahwa modul yang dikembangkan menggunakan metode R \& D dengan model 4-D menurut Thiagarajan et al (1974) yang dimodifikasi menjadi model 3-D. Modul yang dikembangkan layak untuk digunakan dan terbukti mampu meningkatkan pemahaman mahasiswa tentang pencemaran air. Hasil tingkat validitas modul yang dikembangkan didapatkan dari penilaian oleh Pakar. Pakar memberikan penilaian dengan rata-rata skor sebesar 3,25 dan terkategori "baik" untuk dapat digunakan. Kepraktisan modul didapatkan dari uji keterbacaan dan respon mahasiswa terhadap modul yang dikembangkan. Rata-skor untuk uji keterbacaan untuk perorangan dan kelompok kecil, keduanya memperoleh skor 3,0 dan terkategori "baik". Respon mahasiswa diperoleh rata-rata $78,33 \%$ untuk uji perorangan dan $71,67 \%$ untuk uji kelompok kecil, yang berarti untuk kedua uji tersebut terkategori "baik". Efektivitas modul diperoleh dari hasil belajar mahasiswa yaitu dengan membandingkan nilai pretest dan posttest dari mahasiswa. Hasil uji coba untuk menentukan tingkat efektivitas modul, diperoleh $\mathrm{N}$-gain sebegsar 0,9 atau berkategori Tinggi, baik untuk uji coba perorangan maupun kelompok kecil. Hasil ini menunjukkan bahwa modul PBL berbasis lahan basah layak untuk digunakan sebagai bahan ajar pada mata kulih Kimia Lingkungan Lahan Basah.

\section{UCAPAN TERIMAKASIH}

Ucapan terimakasih disampaikan kepada Drs. H. M. Kusasi, M.Pd. dan Drs. Maya Istyadji, M.Pd. yang telah menjadi penelaah dan tim diskusi dalam penelitian ini. Ucapan terimakasih juga disampaikan kepada Dekan FKIP Universitas Lambung Mangkurat (ULM) yang telah memberikan izin dan dukungannya dalam pelaksanaan penelitian ini di lingkungan FKIP ULM.

\section{DAFTAR PUSTAKA}

Aidoo, B., Boateng, S. K., Kissi, P. S., \& Ofori, I. (2016). Effect of problem-based learning on students' achievement in chemistry. Journal of Education and Practice, 7(33), 103-108.

https://www.iiste.org/Journals/index.php/J $\mathrm{EP} /$ article/view/34135

Annafi, N., \& Agustina, S. (2018). Pengembangan model pembelajaran project-based learning (PBL) berbasis kearifan lokal untuk mempersiapkan calon pendidik yang berbudaya. QUANTUM: Jurnal Inovasi Pendidikan Sains, 9(1), 110.

http://dx.doi.org/10.20527/quantum.v9i1. 4854

Ayyildiz, Y., \& Tarhan, L. (2017). Problembased learning in teaching chemistry: enthalpy changes in systems. Research in Science \& Technological Education, http://dx.doi.org/10.1080/02635143.2017. 1366898

Cocozza, J., \& Planner, S. (2009). Economic \& environmental benefits of wetlands. A Dutchess Country Planning Federation Newsletter.

de Graaff, E., \& Kolmos, A. (2003). Characteristics of problem-based learning. International Journal of Engineering Education, 19(5), 657-662. https://www.ijee.ie/articles/Vol195/IJEE1450.pdf

Duch, B. J., Allen, D. E., \& White, H. B. (1997). Problem-based learning: Preparing students to succeed in the 21st century. Essays on Teaching Excellence, 9(7). https://podnetwork.org/content/uploads/V 9-N5-Duch.pdf

Etherington, M. B. (2011). Investigative primary science: A problem-based learning 
approach. Australian Journal of Teacher Education (Online), 36(9), 53-74.

Febriana, B. W., Ashadi, A., \& Masykuri, M. (2014, December). Pengembangan modul kimia berbasis problem-based learning (PBL) pada materi senyawa hidrokarbon dan turunannya kelas XI SMK Kesehatan Ngawi. Prosiding SNPS (Seminar Nasional Pendidikan Sains) (Vol. 1), 1-10.

Febriasari, L. K., \& Supriatna, N. (2017, September). Enhance environmental literacy through problem-based learning. Journal of Physics: Conference Series, 895(1), 012163.

Günter, T., \& Alpat, S. K. (2017). The effects of problem-based learning (PBL) on the academic achievement of students studying 'Electrochemistry'. Chemistry Education Research and Practice, 18(1), 78-98.

https://doi.org/10.1039/C6RP00176A

Günter, T., Akkuzu, N., \& Alpat, Ş. (2017). Understanding 'green chemistry'and 'sustainability': an example of problembased learning (PBL). Research in Science \& Technological Education, 35(4), 500520.https://doi.org/10.1080/02635143.201 7.1353964

Hake, R. R. (1999), Analyzing change/gain scores. Washington DC: American Educational Research Association's Division D, Measurement and Research Methodology.

Hmelo-Silver, C. E. (2004). Problem-based learning: What and how do students learn? Educational Psychology Review, 16(3), 235-266.

https://doi.org/10.1023/B:EDPR.0000034 022.16470.f3

Hmelo-Silver, C. E., \& Barrows, H. S. (2006). Goals and strategies of a problem-based learning facilitator. Interdisciplinary Journal of Problem-Based Learning, 1(1), 21-39. https://doi.org/10.7771/15415015.1004

Hung, W., Jonassen, D. H., \& Liu, R. (2008). Problem-based learning. In M. Spector, D. Merrill, J. Van Merrienböer \& M. Driscoll (Eds.). Handbook of Research on Educational Communications and Technology 3rd Ed. New York: Erlbaum.

Ibrahim, I., Aminudin, N., Young, M. A., \& Yahya, S. A. I. (2012). Education for wetlands: public perception in Malaysia.
Procedia-Social and Behavioral Sciences, 42,

159-165.

https://doi.org/10.1016/j.sbspro.2012.04.1 77

Jeong, A. Y., Shin, S. J., Shin, B. M., \& Bae, S. M. (2017). The development of problembased learning module for clinical dentistry in dental hygiene. Journal of Dental Hygiene Science, 17(5), 383-397. https://doi.org/10.17135/jdhs.2017.17.5.3 83

Kumar, M. (2011). Impact of the evolution of smart phones in education technology and its application in technical and professional studies: Indian perspective. International Journal of Managing Information Technology, 3(3), 39-49. http://airccse.org/journal/ijmit/papers/331 1ijmit04.pdf

Kushartanti, W. (2010). Pendekatan problembased learning dalam pembelajaran praktik kerja lapangan terapi fisik. Jurnal Cakrawala Pendidikan, 29(1), 94-108. doi:https://doi.org/10.21831/cp.v1i1.221

Lestari, T., Fajaruddin, S., \& Sacko, M. (2018, December). Developing booklet-type learning media for improving the students' learning results in computer application data processing course. Proceeding International Seminar.

Lestari, D., \& Projosantoso, A. (2016). Pengembangan media komik IPA model PBL untuk meningkatkan kemampuan berfikir analitis dan sikap ilmiah. Jurnal Inovasi Pendidikan IPA, 2(2), 145-155. https://doi.org/10.21831/jipi.v2i2.7280

Levin, B. B. (2001). Energizing teacher education and professional development with problem-based learning. Virginia: Association for Supervision and Curriculum Development

Mtega, W. P., Bernard, R., Msungu, A. C., \& Sanare, R. (2012). Using mobile phones for teaching and learning purposes in higher learning institutions: the case of Sokoine University of Agriculture in Tanzania. Proceedings and report of the 5th Ubuntu Net Alliance Annual Conference, 118-129. http://www.ubuntunet.net/sites/default/file s/mtegaw.pdf

Ng, S. F., Hassan, N. S. I. C., Nor, N. H. M., \& Malek, N. A. A. M. (2017). The 
relationship between smartphone use and academic performance: a case of students in a Malaysian tertiary institution. Malaysian Online Journal of Educational Technology, 5(4), 58-70.

Parmin, P., \& Peniati, E. (2012). Pengembangan modul mata kuliah strategi belajar mengajar IPA berbasis hasil penelitian pembelajaran. Jurnal Pendidikan IPA Indonesia, l(1). https://doi.org/10.15294/jpii.v1i1.2006

Pedersen, E., Weisner, S. E., \& Johansson, M. (2019). Wetland areas' direct contributions to residents' well-being entitle them to high cultural ecosystem values. Science of the Total Environment, 646, 1315-1326. https://doi.org/10.1016/j.scitotenv.2018.0 7.236

Primarinda, I., Prayitno, B. A., \& Maridi. (2014). Pengembangan modul berorientasi problem-based learning $(P B L)$ pada materi pencemaran untuk memberdayakan kemampuan berpikir kritis dan sikap peduli lingkungan siswa SMA Negeri 1 Karanganyar. Prosiding Seminar Nasional Pendidikan Sains IV 2014, 1-11. http://jurnal.fkip.uns.ac.id/index.php/snps/ article/view/5061

Pummawan, A. (2007). The development of an elearning module on the sandy shores ecosystem for grade-8 secondary students. Educational Journal of Thailand, 1(1), 95110.

Puspadewi, A., \& Syahmani. (2016). Meningkatkan hasil belajar siswa dengan model pembelajaran problem-based learning (PBL) berbantuan modul dalam materi larutan penyangga. QUANTUM: Jurnal Inovasi Pendidikan Sains, 7(1), 1926.

http://dx.doi.org/10.20527/quantum.v7i1. 3537

Ratumanan, T. G., \& Laurens, T. (2003). Evaluasi hasil belajar yang relevan dengan kurikulum berbasis kompetensi. Surabaya: Unesa University Press.

Sanjaya, R. E., \& Iriani, R. (2018). Kualitas air sungai di desa Tanipah (Gambut Pantai), Kalimantan Selatan. BioLink: Jurnal Biologi Lingkungan, Industri dan Kesehatan, $\quad 5(1), \quad 1-10$. http://dx.doi.org/10.31289/biolink.v5i1.15 83
Sari, D., \& Sugiyarto, K. (2015). Pengembangan multimedia berbasis masalah untuk meningkatkan motivasi belajar dan kemampuan berpikir kritis siswa. Jurnal Inovasi Pendidikan IPA, 1(2), 153-166. https://doi.org/10.21831/jipi.v1i2.7501

Savery, J. R. (2006). Overview of problem-based learning: definitions and distinctions. Interdisciplinary Journal of ProblemBased Learning, 1(1), 9-20. https://doi.org/10.7771/1541-5015.1002

Soendjoto, M. A. (2016). Sekilas tentang lahan basah dan lingkungannya. Prosiding Seminar Universitas Lambung Mangkurat 2015, 1-20.

Sukiminiandari, Y. P., Budi, A. S., \& Supriyati, Y. (2015, October). Pengembangan modul pembelajaran fisika denganpendekatan saintifik. Prosiding Seminar Nasional Fisika, 4, 161-164. http://journal.unj.ac.id/unj/index.php/prosi dingsnf/article/view/5000

Sutrisno, S. (2011). Problem-based learning sebagai suatu strategi pembelajaran untuk menumbuh-kembangkan atmosfer kebebasan intelektual. QUANTUM: Jurnal Inovasi Pendidikan Sains, 2(1), 1-12. http://dx.doi.org/10.20527/quantum.v2i1. 3307

Tatar, E., \& Oktay, M. (2011). The effectiveness of problem-based learning on teaching the first law of thermodynamics. Research in Science \& Technological Education, 29(3), 315-332. https://doi.org/10.1080/02635143.2011.59 9318

Thiagarajan, S., Semmel, D. S., \& Semmel, M. I. (1974). Instructional development for training teachers of exceptional children: A sourcebook. Leadership Training Institute/Special Education, University of Minnesota.

Tosun, C., \& Senocak, E. (2013). The effects of problem-based learning on metacognitive awareness and attitudes toward chemistry of prospective teachers with different academic backgrounds. Australian Journal of Teacher Education, 38(3), 126131.

http://dx.doi.org/10.14221/ajte.2013v38n3 .2

Tosun, C., \& Taskesenligil, Y. (2012). The effect of problem-based learning on student 
Jurnal Inovasi Pendidikan IPA, 5 (1), 2019 - 68

Rilia Iriani, Anna Herlina, Yudha Irhasyuarna, Rahmat Eko Sanjaya

motivation towards chemistry classes and on learning strategies. Journal of Turkish Science Education, 9(1), 104-125.

Utaminingsih, R., Rahayu, A., \& Andini, D. (2018). Pengembangan RPP IPA sekolah dasar berbasis problem-based learning untuk siswa learning disabilities. Jurnal Inovasi Pendidikan IPA, 4(2), 191-202. https://doi.org/10.21831/jipi.v4i2.21401

Wati, R., Rusmansyah, \& Sholahuddin, A. (2014). Meningkatkan kemampuan berpikir kritis dan hasil belajar siswa kelas XI IPA 2 SMA PGRI 4 Banjarmasin pada konsep sistem koloid melalui model problem-based learning. QUANTUM: Jurnal Inovasi Pendidikan Sains, 5(2), 2031. http://dx.doi.org/10.20527/quantum.v5i2. 1197

Widoyoko, E. P. (2013). Evaluasi program pembelajaran. Yogyakarta: Pustaka Pelajar.
Wikhdah, I., Sumarti, S., \& Wardani, S. (2016). Pengembangan modul larutan penyangga berorientasi chemoentrepreneurship (CEP) untuk kelas XI SMA/MA. Jurnal Inovasi Pendidikan Kimia, 9(2), 1585-1595. Retrieved from https://journal.unnes.ac.id/nju/index.php/J IPK/article/view/4826

Yarid, H., \& Ariswan, A. (2016). Pengembangan perangkat pembelajaran fisika problembased learning melalui kegiatan fieldtrip pada materi energi. Jurnal Inovasi Pendidikan IPA, 2(1), 24-34. https://doi.org/10.21831/jipi.v2i1.8374

Yew, E. H. J., \& Goh, K. (2016). Problem-based learning: an overview of its process and impact on learning. Health Professions Education, 2, 75-79. https://doi.org/10.1016/j.hpe.2016.01.004 